Jurnal Viabel Pertanian Vol. 13 No. 1 Mei 2019

p-ISSN: 1978-5259 e-ISSN: 2527-3345

Copyright@UNISBA Blitar, http://ejournal.unisbablitar.ac.id/index.php/viabel

Intan Fuji Arriani, Luqman Qurata Aini , Restu Rizkyta Kusuma 2019. Pemanfaatan Bakteri

Antagonis Lumpur Sidoarjo Untuk Menekan Sclerotium Rolfsii Sacc. Penyebab Penyakit

Rebah Semai Pada Tanaman Kedelai Journal Viabel Pertanian. (2019), 13(1)11-20

\title{
PEMANFAATAN BAKTERI ANTAGONIS LUMPUR SIDOARJO UNTUK MENEKAN Sclerotium rolfsii Sacc. PENYEBAB PENYAKIT REBAH SEMAI PADA TANAMAN KEDELAI
}

\author{
Intan Fuji Arriani, Luqman Qurata Aini , Restu Rizkyta Kusuma \\ Fakultas Pertanian Universitas Brawijaya \\ Fakultas Pertanian Universitas Brawijaya Jl. Veteran, Kota Malang, Jawa Timur 65145 \\ Intanfuji485@gmail.com
}

\begin{abstract}
Soybean plants is a strategic commodity in Indonesia, because soybean is an important crop food after rice and maize. One of the important diseases that attack soybean plants is damping off caused by pathogenic fungi $S$. rolfsii. One effort to suppress attack from pathogenic fungi it $S$. rolfsii attack is by using biological agents. Trial of antagonistic bacteria with fungi $S$. rolfsii stepin vitro is test the artificial media (media NA). The result of the selection of the lumpur Sidoarjo bacterial isolates obtained 15 and 5 bacteria have antagonistic properties against pathogenic fungi $S$. rolfsii is isolates LUSI 93, LUSI 43, LUSI 16, LUSI 6, and LUSI 54. The identification and characterization of antagonistic bacteria lumpur Sidoarjo is LUSI 93 belongs to the genus Vibrio sp. And for LUSI 54, 16 LUSI, LUSI 43, and LUSI 6 has been identified by previous research in a row belongs to the genus Corynebacterium sp, Vibrio sp, Erwinia sp and Corynebacterium sp.
\end{abstract}

Keyword : Corynebacterium sp, Erwinia sp, rebah semai, Sclerotium rolfsii, Vibrio sp

\section{PENDAHULUAN}

Tanaman kedelai (Glycine max (L.) Merrill) merupakan komoditas strategis di Indonesia karena kedelai merupakan tanaman pangan di Indonesia yang cukup penting setelah beras dan jagung.Peningkatan produktivitas kedelai tidak terlepas dari berbagai kendala, antara lain adanya gangguan organisme pengganggu tanaman. Salah satu penyakit yang cukup penting adalah penyakit rebahemai atau busuk pangkal batangg yang disebabkan oleh Sclerotium rolfsii.Jamur Sclerotium rolfsii sulit ditanggulangi karena mampu bertahan selama bertahun-tahun di dalam tanah dalam bentuk sklerotia dan mempunyai kisaran inang yang luas (Semangun, 1993).

Pengendalian penyakit rebah semai atau busuk pangkall batang umumnya masih menggunakan pestisida kimia.Pengendalian hayati dengan penggunaan mikroorganisme antagonis semakin mendapat perhatian dalam perlindungan tanaman dan memiliki potensi untuk dikembangkan sebagai teknik alternatif dalam mengendalikan penyakit busuk pangkal batang.Kemampuan bakteri sebagai agens hayati dipengaruhi oleh beberapa faktor salah satunya kondisi lingkungan.Kawasan lumpur Sidoarjo merupakan salah satu kawasan lingkungan ekstreme dan diduga terdapat mikroorganisme yang mampu tumbuh, bakteri yang 
Jurnal Viabel Pertanian Vol. 13 No. 1 Mei 2019

p-ISSN: 1978-5259 e-ISSN: 2527-3345

Copyright@UNISBA Blitar, http://ejournal.unisbablitar.ac.id/index.php/viabel

Intan Fuji Arriani, Luqman Qurata Aini , Restu Rizkyta Kusuma 2019. Pemanfaatan Bakteri

Antagonis Lumpur Sidoarjo Untuk Menekan Sclerotium Rolfsii Sacc. Penyebab Penyakit

Rebah Semai Pada Tanaman Kedelai Journal Viabel Pertanian. (2019), 13(1)11-20

mampu hidup dilingkungan ekstrem memiliki efisiensi yang tinggi dan mampu menyesuaikan diri pada berbagai kondisi lingkungan. Oleh karena itu, penelitian ini dilakukan untuk mendapatkan, mengkaji kemampuan, serta mengidentifikasi secara biokimia bakteri dari lumpur Sidoarjo yang mempunyai sifat antagonis dengan jamur patogen $S$. rolfsii penyebab penyakit rebah semai atau bbusuk pangkal batang pada tanaman kedelai.

\section{BAHAN DAN METODE PENELITIAN}

\section{Uji Penghambatan Jamur Patogen S. rolfsii dengan Bakteri Antagonis dengan teknikIn Vitro}

Penelitian teknikin vitro dilakukan dengan menggunakan Rancangan Acak Lengkap (RAL). Perlakuan yang digunakan yaitu (kontrol, fungisida dan 5 isolat bakteri antagonis lumpur Sidoarjo terpilih) dan diulang 4 kali.Perlakuan bakteri lumpur Sidoarjo menggunakan kerapatan $10^{9} \mathrm{cfu} / \mathrm{ml}$. Bakteri.Uji antagonis bakteri lumpur Sidoarjo dengan jamur patogen $S$. rolfsii dilakukan dengan mencelupkan kertas saring pada larutan NB $10 \mathrm{ml}$ yang telah ditanam isolat bakteri sebanyak 1 ose dan dishaker selama $2 \times 24$ jam selama 1 menit dan fungisida kimia dengan bahan aktif piraklostrobin dengan dosis $0,25 \mathrm{ml} / \mathrm{L}$. Aktivitas penghambatan ditentukan berdasarkan zona hambat yang terbentuk disekitar koloni.

\section{Identifikasi dan Karakterisasi Bakteri Antagonis Lumpur Sidoarjo}

Identifikasi dan karakterisasi bakteri antagonis lumpur Sidoarjo dilakukan berdasarkan menurut Bergey's Manual of Determinative Bacteriology (1994) dan Schaad (2001).Bakteri antagonis yang diidentifikasi berdasarkan hasil seleksi yang bersifat antagonis terhadap $S$. rolfsii.

\section{Reaksi Gram}

Pengujian reaksi denga KOH.Biakan murni bakteri antagonis yang berumur 24 jam disuspensikan diatas gelas objek yang sebelumnya telah ditetesi dengan KOH $3 \%$. Kemudian diaduk menggunakan jarum ose. Suspensi bakteri yang membentuk lendir menunjukkan bakteri termasuk Gram negatif. Apabila suspensi tidak terangkat dengan jarum ose atau encer, menunjukkan bakteri Gram positif.

Pengujian Gram.Biakan murni bakteri antagonis yang berumur 24 jam dibuat suspensi dengan aquades steril diatas gelas objek yang telah disterilkan dan dikeringkan diatas pemanas Bunsen.Kemudian dilakukan pengecatan dengan Kristal violet, setelah itu ditetesi dengan idodin 1-2 tetes dan dibiarkan selama 1 menit.Selanjutnya cuci dengan alkohol $70 \%$ dibiarkan hingga 20 detik kemudian dicuci dengan air mengalir dan dikeringanginkan. Proses terakhir ditetesi sfranin dibiarkan selama 20 detik dan dicuci dengan air mengalir, dikeringanginkan dan diamati dibawah mikroskop. Sel bakteri Gram negatif berwarna bewarna merah sedangkan sel bakteri Gram positif bewarna ungu.

Pewarnaan Spora. Bakteri yang berumur 24 jam dibuat suspensi dengan aquades steril diatas gelas objek yang telah disterilkan dan dikeringkan diatas lampu Bunsen fiksasi bakteri yang akan diamati, kemudian genangi olesan bakteri dengan malachite green yang diletakkan diatas pemanas selama 2-3 menit, setelah itu ditetesi safranin selama 30 detik, kemudian 
Jurnal Viabel Pertanian Vol. 13 No. 1 Mei 2019

p-ISSN: 1978-5259 e-ISSN: 2527-3345

Copyright@UNISBA Blitar, http://ejournal.unisbablitar.ac.id/index.php/viabel

Intan Fuji Arriani, Luqman Qurata Aini , Restu Rizkyta Kusuma 2019. Pemanfaatan Bakteri

Antagonis Lumpur Sidoarjo Untuk Menekan Sclerotium Rolfsii Sacc. Penyebab Penyakit

Rebah Semai Pada Tanaman Kedelai Journal Viabel Pertanian. (2019), 13(1)11-20

dicuci dengan aquades dan dikeringkan. Proses terakhir diamati dibawah mikroskop sampai perbesaran 1000x menggunakan minyak emersi. Pengamatan spora berupa sel bakteri akan bewarna merah, jika sel membentuk spora maka spora akan bewarna hijau.

\section{Uji Hipersensitif}

Metode untuk uji hipersensitif mengacu pada Schaad et al., (2001), uji hipersensitif merupakan uji yang dilakukan untuk mengetahui sifat patogenik suatu bakteri. Bakteri dipanen dengan aquades steril kemudian suspensi bakteri diinokulasikan pada bagian tulang daun tembakau sebanyak $1 \mathrm{ml}$. Reaksi hipersensitif akan menunjukkan gejala nekosis pada bagian daun. Perkembangan gejala yang ditimbulkan diamati sampai 7 hari.

\section{Uji Oksidase}

Uji oksidase dilakukan untuk membedakan karakteristik dari genus Pseudomonas.Pengujian menggunakan kertas whatman dan ditetesi 3-4 tetes $1 \%$ larutan tertamethyl paraphenyliene diamine dihydrochloride. Selanjutnya mengambil 1 ose bakteri berumur 24 jam kemudian diletakkan pada kertas whatman yang telah ditetesi. Perubahan warna setelah 10 detik menunjukkan reaksi positif (Pratita dan Putra, 2012).

\section{Uji Fermentasi Glukosa}

Media basal terdiri atas: Pepton 2 gr; $\mathrm{NaCl} 5$ gr, KH2PO4 0,3 g r, Agar 3 gr, Bromothymolblue (1\%) $3 \mathrm{ml}$. Bahan-bahan tersebut dilarutkan dalam aquades dan diukur $\mathrm{pH}$ 7,1. Media disterilkan pada $121^{\circ} \mathrm{C}$ selama 25 menit. Setelah disterilisasi, setiap tabung ditambahkan dengan 0,5 ml larutan glukosa $10 \%$ secara aseptis. Selanjutnya isolat bakteri endofit berumur 24 jam ditusukkan kedalam media pada kedua tabung tersebut. Salah satu tabung ditutup dengan parafin cair steril sebanyak $2 \mathrm{ml}$ dan tabung lainnya dibiarkan terbuka (tanpa parafin cair).Kemudian kedua tabung diinkubasikan selama 7-14 hari.Reaksi fermentatif apabila terjadi perubahan warna media dari biru menjadi kuning pada kedua tabung atau hanya pada tabung yang ditutup dengan minyak parafin.Hal ini menunjukkan hasil positif.

\section{5. $\mathbf{U j i ~} \mathrm{Na}^{+}$}

Uji $\mathrm{Na}^{+}$dilakukan dengan cara menumbuhkan bakteri pada media $\mathrm{NA}+\mathrm{NaCl}$ 6\%. Reaksi positif ditunjukkan dengan tumbuhkan bakteri pada media dan reaksi negative ditunjukkan dengan tidak tumbuhkan bakteri pada media $\mathrm{Na}^{+}$(Pratita dan Putra, 2012).

\section{HASIL DAN PEMBAHASAN}

\section{Seleksi Isolat Bakteri Lumpur Sidoarjo yang Bersifat Antagonis Terhadap S. rolfsii secara In Vitro}

Pada penelitian ini dilakukan seleksi 15 isolat yang mampu menghambat $S$. rolfsii pada cawan Petri.Seleksi yang dilakukan dengan menggunakan metode oposisi langsung.Daya antagonis ditandai dengan zona hambat yang dihasilkan antara jamur $S$. rolfsii 
Jurnal Viabel Pertanian Vol. 13 No. 1 Mei 2019

p-ISSN: 1978-5259 e-ISSN: 2527-3345

Copyright@UNISBA Blitar, http://ejournal.unisbablitar.ac.id/index.php/viabel

Intan Fuji Arriani, Luqman Qurata Aini , Restu Rizkyta Kusuma 2019. Pemanfaatan Bakteri

Antagonis Lumpur Sidoarjo Untuk Menekan Sclerotium Rolfsii Sacc. Penyebab Penyakit

Rebah Semai Pada Tanaman Kedelai Journal Viabel Pertanian. (2019), 13(1)11-20

dengan bakteri antagonis lumpur Sidoarjo.Hasil seleksi diperoleh 5 isolat yang mampu menghambat $S$. rolfsiiTabel 1.

Table 1. Pengaruh jenis isolate bakteri lumpur Sidoarjo terhadap pembentukan zona hambat pada pertumbuhan $S$. rolfsii 48 jam setelah inokulasi.

\begin{tabular}{ll}
\hline Kode Isolat & Zona Hambat \\
\hline LUSI 1 & - \\
LUSI 2 & - \\
LUSI 3 & - \\
LUSI 4 & - \\
LUSI 5 & - \\
LUSI 6 & + \\
LUSI 7 & - \\
LUSI 8 & - \\
LUSI 9 & - \\
LUSI 10 & - \\
LUSI 43 & + \\
LUSI 45 & - \\
LUSI 93 & + \\
LUSI 16 & + \\
LUSI 54 & + \\
\hline
\end{tabular}

Keterangan : Zona hambat dalam satuan cm. LUSI : Lumpur Sidoarjo

\section{Penghambatan Pertumbuhan Jamur S. rolfsii dengan Bakteri Antagonis secara In Vitro}

Hasil analisis menunjukkan bakteri antagonis lumpur Sidoarjo berpengaruh nyata dalam menghambat pertumbuhan jamur $S$. rolfsii, ditandai dengan adanya nilai yang berbeda nyata dengan perlakuan kontrol positif.Hasil uji daya antagonis bakteri lumpur Sidoarjo disajikan pada pada tabel 2 .

Table 2. Rerata Presentase Penghambatan Mikroba Antagonis terhadap jamur S. rolfsii secara In Vitro

\begin{tabular}{llll}
\hline \multicolumn{4}{l}{ Waktu Pengamatan } \\
\hline P1 (Fungisida) & 48 JST & 72 JST & 96 JST \\
P2 Isolat LUSI 93 & $21.04 \mathrm{~b}$ & $26.58 \mathrm{a}$ & $39.63 \mathrm{a}$ \\
P3 Isolat LUSI 54 & $25.91 \mathrm{~b}$ & $35.84 \mathrm{a}$ & $62.70 \mathrm{c}$ \\
P4 Isolat LUSI 43 & $13.47 \mathrm{a}$ & $32.32 \mathrm{a}$ & $53.32 \mathrm{~b}$ \\
P5 Isolat LUSI 16 & $22.69 \mathrm{~b}$ & $23.62 \mathrm{a}$ & $40.39 \mathrm{a}$ \\
P6 Isolat LUSI 6 & $13.06 \mathrm{a}$ & $34.50 \mathrm{a}$ & $55.84 \mathrm{bc}$ \\
\hline
\end{tabular}

Keterangan :Angka yang diikuti huruf yang sama pada kolom pengamatan yang sama menunjukkan tidak berbeda nyata pada uji Duncan taraf $5 \%$; Kontrol (P00):aplikasi menggunakan aquadest steeril. Keterangan : JST (Jam setelah tanam), LUSI : Lumpur Sidoarjo.

Hasil analisis ragam menunjukkan bahwa perlakuan bakteri antagonis berpengaruh nyata terhadap pertumbuhan S.rofsii secara in vitro. Hasil pengamatan pada 48 jam setelah tanam menunjukkan perlakuan P1 (Fungisida), P2 (Isolat LUSI 93), dan P4 (Isolat LUSI 43) 
Jurnal Viabel Pertanian Vol. 13 No. 1 Mei 2019

p-ISSN: 1978-5259 e-ISSN: 2527-3345

Copyright@UNISBA Blitar, http://ejournal.unisbablitar.ac.id/index.php/viabel

Intan Fuji Arriani, Luqman Qurata Aini , Restu Rizkyta Kusuma 2019. Pemanfaatan Bakteri

Antagonis Lumpur Sidoarjo Untuk Menekan Sclerotium Rolfsii Sacc. Penyebab Penyakit

Rebah Semai Pada Tanaman Kedelai Journal Viabel Pertanian. (2019), 13(1)11-20

memiliki nilai rata-rata persentase kemampuan menghambat $S$.rolfsii yang sama. Hal tersebut juga terjadi pada perlakuan P3 ( Isolat LUSI 54), P5 (Isolat LUSI 16), dan P6 (Isolat LUSI 6) yang memiliki nilai rata-rata persentase kemampuan menghambat $S$. rolfsii yang sama. Persentase penghambatan tertinggi ditunjukkan pada perlakuan P2 (Isolat LUSI 93) sebesar $25.91 \%$ dan persentase penghambatan terendah ditunjukkan pada P5 (Isolat LUSI 16 yaitu kontrol sebesar $13.06 \%$.

Hasil analisis ragam pengamatan pada 72 jam setelah tanam menunjukkan perlakuan P1 (Fungisida), P2 (Isolat LUSI 93), P3 ( Isolat LUSI 54), P4 (Isolat LUSI 43), P5 (Isolat LUSI 16), dan P6 (Isolat LUSI 6) memiliki nilai rata-rata persentase kemampuan menghambat $S$. rolfsii yang sama. Persentase penghambatan tertinggi ditunjukkan pada perlakuan P2 ( Isolat LUSI 93) sebesar $35.84 \%$ dan persentase penghambatan terendah ditunjukkan pada P1 (Fungisida) yaitu kontrol sebesar $26.58 \%$.

Hasil analisis ragam) pengamatan pada 96 jam setelah tanam menunjukkan perlakuan P1 (Fungisida) dan P4 (Isolat LUSI 43), P3 (Isolat LUSI 54) dan P6 (Isolat LUSI 6) memiliki nilai rata-rata persentase kemampuan menghambat $S$. rolfsii yang sama. Persentase penghambatan tertinggi ditunjukkan pada perlakuan P2 ( Isolat LUSI 93) sebesar $62.70 \%$ dan persentase penghambatan terendah ditunjukkan pada P1 (Fungisida) sebesar $39.53 \%$.

Hasil uji antagonis yang telah dilakukan, isolat bakteri lumpur Sidoarjo mampu menghambat pertumbuhan $S$. rolfsii.Mekanisme antagonis bakteri lumpur Sidoarjo terhadap jamur $S$. rolfsii tergolong antibiosis. Antibiosis adalah proses penghambatan pertumbuhan suatu mikroorganisme pada lingkungan yang sama (Bentley dan Bennett, 2003). Hal tersebut dapat dilihat adanya pertumbuhan abnormal pada sel-sel jamur patogen $S$. rolfsii sehingga miselium tidak mampu tumbuh dengan sempurna, ditandai dengan adanya zona kosong pada sekeliling bakteri antagonis. 
Intan Fuji Arriani, Luqman Qurata Aini , Restu Rizkyta Kusuma 2019. Pemanfaatan Bakteri Antagonis Lumpur Sidoarjo Untuk Menekan Sclerotium Rolfsii Sacc. Penyebab Penyakit Rebah Semai Pada Tanaman Kedelai Journal Viabel Pertanian. (2019), 13(1)11-20

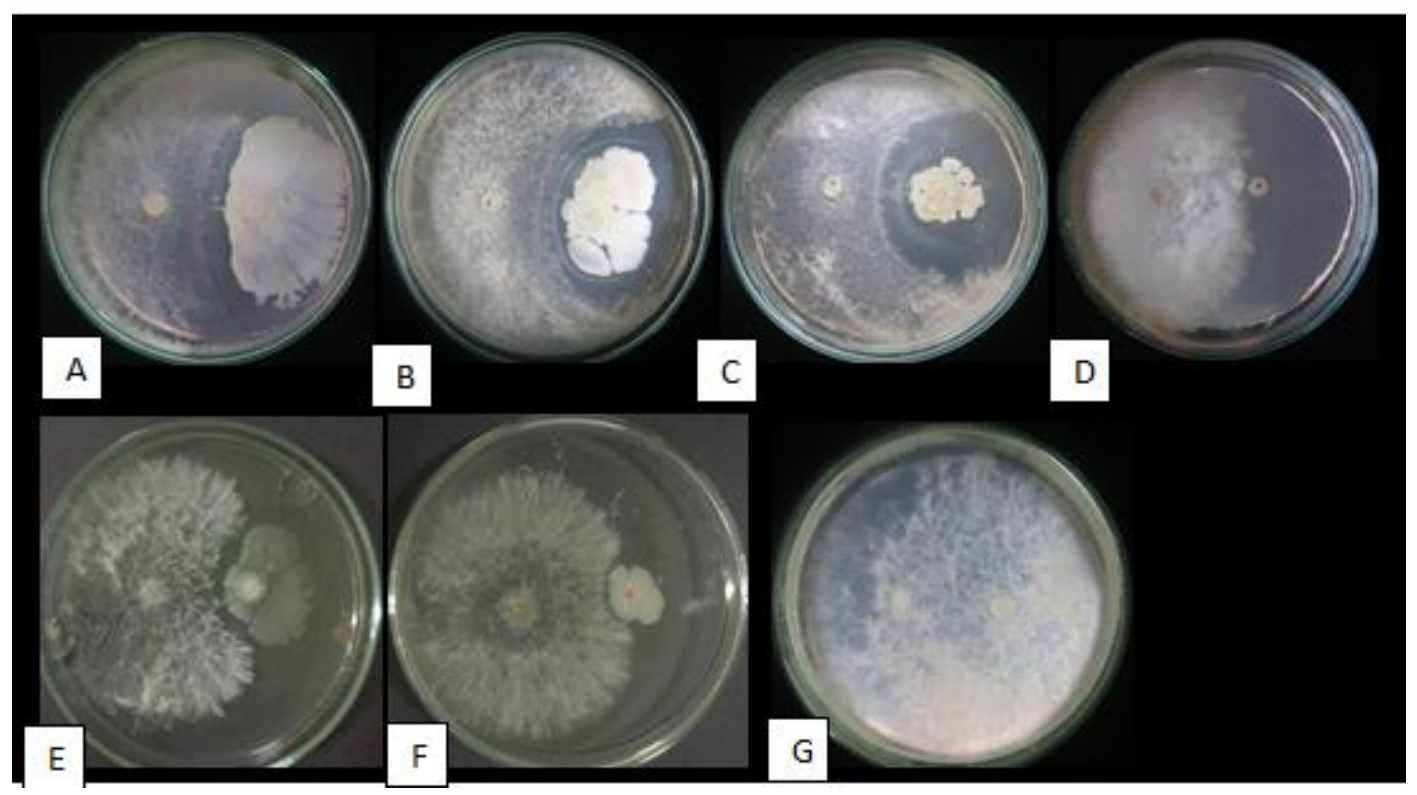

Gambar 1.Uji Miroba Antagonis pada pertumbuhan S.rolfsii di media NA. Keterangan : (A) Isolat LUSI 6, (B) Isolat LUSI 54, (C) Isolat LUSI 93, (D) Fungisida, (E) Isolat LUSI 16, (F) Isolat LUSI 43, (G) Kontrol (aquades steril).

Zona hambat yang dihasilkan pada uji antagonis diduga karena adanya senyawa metabolit yang dikeluarkan oleh bakteri lumpur Sidoarjo, sehingga menyebabkan terhambatnya pertumbuhan miselium jamur patogen S. rolfsii.Menurut Zhang (2004) kemampuan suatu agens hayati dalam menekan patogen biasanya melibatkan satu atau beberapa mekanisme penghambatan, diantaranya dengan menghasilkan antibiotik, toksin, kompetisi ruang dan nutrisi, menghasilkan siderofor, dan HCN. Penghambatan pada masingmasing bakteri antagonis berbeda-beda.Adanya perbedaan penghambatan suatu bakteri terjadi karena senyawa antibiotik yang dihasilkan setiap bakteri berbeda (Raharini et al., 2012).

Perlakuan P3 dengan isolat LUSI 93 pada setiap pengamatan mengalami kenaikan.Secara berturut-turut persentase daya hambat sebesar $25.91 \%, 35.84 \%, 62.7$ $\%$.Sedangkan pengamatan pada perlakuan fungisida setiap pengamatan juga mengalami kenaikan dengan persentase daya hambat sebesar $21.04 \%, 26.58 \%, 39.63 \%$. Hal tersebut menunjukkan bahwa perlakuan dengan menggunakan mikroba antagonis memiliki kemampuan sama dengan perlakuan fungisida dalam menghambat pertumbuhan S.rolfsii. Penelitian yang telah dilakukan menunjukkan bahwa piraklostrobin memiliki sifat preventif dan kuratif terhadap sejumlah penyakit tanaman. Proses penghambatan pada patogen jamur hampir terjadi pada tahapan utama dari siklus hidup seperti spora, pertumbuhan miselium, dan sporulasi. Lebih teknis, molekul-molekul ini menghambat pada respirasi mitokondria dalam sel jamur (Uddin, 2001). 
Intan Fuji Arriani, Luqman Qurata Aini , Restu Rizkyta Kusuma 2019. Pemanfaatan Bakteri Antagonis Lumpur Sidoarjo Untuk Menekan Sclerotium Rolfsii Sacc. Penyebab Penyakit Rebah Semai Pada Tanaman Kedelai Journal Viabel Pertanian. (2019), 13(1)11-20

\section{Karakteristik dan Identifikasi Bakteri Lumpur Sidoarjo}

\section{Karakteristik Morfologi}

Pembiakan bakteri dilakukan dengan melakukan streak tunggal agar didapatkan koloni tunggal yang akan diamati. Terdapat 5 kode yang bersifat antagonis terhadap $S$. rolfsii dengan 4 kode sudah diidentifikasi oleh penelitian sebelumnya yaitu kode LUSI 6, LUSI 54, LUSI 43, LUSI 16. Berikut ini hasil pengamatan morfologi dari isolate bakteri Lumpur Sidoarjo yang belum teridentifikasi seperti tabel 3 .

Tabel 3. Morfologi Isolat Bakteri Lumpur Sidoarjo yang Bersifat Antagonis terhadap S. rolfsii

\begin{tabular}{lllll}
\hline \multicolumn{5}{c}{ Morfologi Koloni } \\
\hline Isolat & Bentuk & Permukaan & Warna & Tepi \\
\hline LUSI 93 & Bulat & Cembung & Putih & Rata \\
\hline
\end{tabular}

Keterangan : Morfologi bakteri yang digoreskan di media NA, LUSI :Lumpur Sidoarjo

Hasil pengamatan morfologi bakteri didapatkan dari hasil koloni tunggal seperti gambar dibawah ini gambar 2.

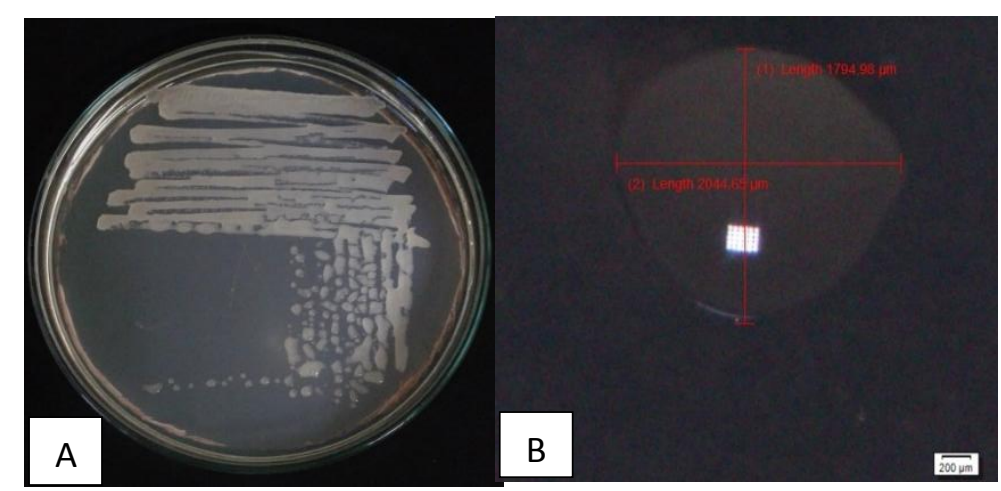

Gambar 2.Bentuk koloni tunggal pada media NA.Keterangan : Morfologi bakteri yang digoreskan di media NA. (A) bentuk koloni pada media NA kode LUSI-93 ; (B) Bentuk koloni tunggal kode LUSI 93

\section{Karakteristik Biokimia}

Pengujian fisiologi dan biokimia pada tabel 5 meliputi uji hipersensitif, pengujian gram, pengecatan spora, pengujian $\mathrm{KOH} 3 \%$, uji oksidase, fermentative glukosa, dan pertumbuhan pada media $\mathrm{NA}^{+}$. Berikut ini hasil pengamatan karakteristik fisiologi dan biokimia dari isolate bakteri Lumpur Sidoarjo yang belum teridentifikasi seperti tabel 4 . 
Jurnal Viabel Pertanian Vol. 13 No. 1 Mei 2019

p-ISSN: 1978-5259 e-ISSN: 2527-3345

Copyright@UNISBA Blitar, http://ejournal.unisbablitar.ac.id/index.php/viabel

Intan Fuji Arriani, Luqman Qurata Aini , Restu Rizkyta Kusuma 2019. Pemanfaatan Bakteri

Antagonis Lumpur Sidoarjo Untuk Menekan Sclerotium Rolfsii Sacc. Penyebab Penyakit

Rebah Semai Pada Tanaman Kedelai Journal Viabel Pertanian. (2019), 13(1)11-20

Table 4. Karakteristik biokimia bakteri lumpur Sidoarjo yang digunakan dalam pengujian in vitro Karakter LUSI 93

Uji Reaksi Gram

a. $\mathrm{KOH} 3 \%$

b. Pengecatan gram

Pengecatan spora

$\mathrm{TU}$

Uji OF

a. Anaerob TU

b. Fermentasi Glukosa + +

Uji Katalase TU

Uji Oksidase +

Hipersentsitif -

Pertumbuhan di $\mathrm{NA}^{+}+$

Keterangan : Karakteristik fisiologi dan biokimia terpilih Lumpur Sidoarjo. (+) : reaksi positif, (-) : reaksi negatif, (TU) : Tidak dilakukan uji. Isolat LUSI 93 termasuk kedalam genus Vibrio spp.

Hasil karakterisasi bakteri secara biokimia berdasarkan Bergey's Manual of Determinative Bacteriology (1994) dan Schaad (2001) menunjukkan bahwa Isolat LUSI 93 menunjukkan karakteristik memiliki bentuk bulat, warna putih, tepi rata, dan permukaan berbentuk cembung. Pada pengujian fisiologis dan biokimia diketahui bahwa bakteri Lumpur Sidoarjo gram negatif berbentuk basil, uji oksidase bereaksi positif, pada uji frementasi glukosa bereaksi positif, dan pengujian pada media $\mathrm{NA}^{+}$bersifat positif. Menurut Bergey's Manual of Determinative Bacteriology (1994) dan Schaad (2001) bakteri dengan ciri-ciri tersebut dapat dikelompokkan dalam genus Vibrio spp.

Isolat LUSI 43 dan LUSI 54 telah diidentifikasi oleh penelitian Daulika (2016) yang menunjukkan bakteri berbentuk bulat, permukaan cembung, warna putih keruh, dan tepi rata. Hasil Fisiologi dan Biokimia termasuk kedalam bakteri gram negatif dengan bentuk basil, hasil oksidase negatif, hasil uji fermentasi glukosa bersifat fermentatif, pertumbuhan pada media YDC negatif, dan termasuk kedalam genus Erwinia sp.

Isolat LUSI 6 telah diidentifikasi oleh penelitian Daulika (2016) yang menunjukkan bakteri berbentuk bulat, permukaan rata, warna putih, dan tepi bergerigi.Hasil Fisiologi dan Biokimia termasuk kedalam bakteri gram positif dengan bentuk basil, tidak memiliki endospora, hasil uji Katalase bereaksi positif, dan termasuk kedalam genus corynebacterium sp.

Isolat LUSI 16 telah diidentifikasi oleh penelitian Daulaya (2015) yang menunjukkan Bakteri Lumpur Sidoarjo memiliki bentuk bulat, warna putih kekuningan, tepi rata, dan permukaan berbentuk cembung. Pada pengujian fisiologis dan biokimia diketahui bahwa bakteri Lumpur Sidoarjo gram negatif berbentuk basil, pada uji frementasi glukosa bereaksi negatif, dan pengujian pada media NA+ bersifat positif, dan termasuk kegalam genus Vibrio spp. 
Jurnal Viabel Pertanian Vol. 13 No. 1 Mei 2019

p-ISSN: 1978-5259 e-ISSN: 2527-3345

Copyright@UNISBA Blitar, http://ejournal.unisbablitar.ac.id/index.php/viabel

Intan Fuji Arriani, Luqman Qurata Aini , Restu Rizkyta Kusuma 2019. Pemanfaatan Bakteri

Antagonis Lumpur Sidoarjo Untuk Menekan Sclerotium Rolfsii Sacc. Penyebab Penyakit

Rebah Semai Pada Tanaman Kedelai Journal Viabel Pertanian. (2019), 13(1)11-20

\section{Kesimpulan}

\section{KESIMPULAN DAN SARAN}

1. Hasil seleksi dari 15 isolat terdapat 5 isolat yang mampu menghasilkan zona hambat dalam menekan pertumbuhan jamur patogen $S$. rolfsii.

2. Perlakuan bakteri antagonis lumpur Sidoarjo mampu menghambat pertumbuhan jamur patogen $S$. rolfsii secara in vitro. Persentase daya hambat terbaik pada Saran perlakuan LUSI 93 dengan genus Vibrio sp sebesar $62.70 \%$.

Perlu dilakukan penelitian lebih lanjut untuk mengetahui potensi bakteri lumpur Sidoarjo dalam skala lapang untuk menekan penyakit Rebah Semai sehingga bisa menjadi pengendalian yang lebih efektif dalam menekan penyakit Rebah Semai pada tanaman kedelai.

\section{DAFTAR PUSTAKA}

Schaad, N. W., Jones, J. B. dan Chun, W. 2001. Laboratory Guide for Identification of Plant Pathogen Bacteria.Ed ketiga.APS Press. St. Paul Minnessota.

Daulay, D, M. 2015.Potensi Bakteri Bermanfaat Dari Lumpur Sidoarjo Untuk Mengendalikan Penyakit Busuk Lunak Erwinia sp. Pada Umbi Kentang.

Daulika, S. 2016. Potensi Bakteri dari Lumpur Sidoarjo sebagai Agens Pengendali Hayati Penyakit Layu Bakteri (Ralstonia solanacearum) pada Tanaman Tomat. Skripsi Fakultas Pertanian. Universitas Brawijaya.

Bentley, Ronald dan Bennett, J.W. 2003. What is an Antibiotic? Revisited.Departement of Biological Science.University of Pittsburgh.

Jayasumarta, D. 2012. Pengaruh system olah tanam dan pupuk $\mathrm{p}$ terhadap pertumbuhan dan produksi tanaman kedelai (G.max).Fakultas pertanian. Universitas Muhamadyah. Sumatra utara.

Pratita, M.Y.E. dan Putra, S.R. 2012.Isolasi Dan Identifikasi Bakteri Termofilik Dari Sumber Mata Air Panas Di Songgoriti Setelah Dua Hari Inkubasi. Jurusan Kimia, Fakultas Matematika dan Ilmu Pengetahuan Alam, Institut Teknologi Sepuluh Nopember (ITS). 1 (1) : 1-3.

Raharini, A.O., Kawuri, Retno., dan Khalimi, Khamdan. 2012. Penggunaan Streptomyces sp. Sebagai Biokontrol Penyakit Layu Pada Tanaman Cabai Merah (Capsicum annuum L.) yang Disebabkan Oleh Fusarium oxysporum f.sp.capsici. Fakultas Pertanian. Universitas Udayana. 2 (2) :155.

Semangun, H. 1993. Penyakit-penyakit Tanaman Hortikultura di Indonesia. Gadjah Mada University Press.Yogjakarta. 
Jurnal Viabel Pertanian Vol. 13 No. 1 Mei 2019

p-ISSN: 1978-5259 e-ISSN: 2527-3345

Copyright@UNISBA Blitar, http://ejournal.unisbablitar.ac.id/index.php/viabel

Intan Fuji Arriani, Luqman Qurata Aini , Restu Rizkyta Kusuma 2019. Pemanfaatan Bakteri Antagonis Lumpur Sidoarjo Untuk Menekan Sclerotium Rolfsii Sacc. Penyebab Penyakit Rebah Semai Pada Tanaman Kedelai Journal Viabel Pertanian. (2019), 13(1)11-20

Uddin, Wakar. 2001. Pyraclostrobin: A promising new fungicide for turfgrass professionals. http://archive.lib.msu.edu/tic/tgtre/article/2001nov4.pdf.

Zhang, Yulian. 2004. Biocontrol Sclerotina Stem Rot of Canola by Bacterial Antagonist and Study of Biocontrol Mechanism Involved. Thesis.University of Manitoba. 